\title{
Pharmacognostic Study of Collection and Study of its Hepatoprotective Activity
}

\author{
Lubsandorzhieva PB ${ }^{1, *}$, Rendyuk TD², Dashinamzhilov Zh.B' ${ }^{1}$, Dargaeva TD³, Ferubko EV ${ }^{3}$
}

\section{Lubsandorzhieva PB ${ }^{1, *}$, Rendyuk TD $^{2}$, Dashinamzhilov Zh. B', Dargaeva TD ${ }^{3}$, Ferubko EV ${ }^{3}$}

'Institute of General and Experimental Biology of the Siberian Branch of the RAS, Ulan-Ude, RUSSIA.

${ }^{2}$ Sechenov First Moscow State Medical University, Moscow, RUSSIA.

${ }^{3}$ All-Russian Research Institute of medicinal and Aromatic Plants, Moscow, RUSSIA.

\section{Correspondence}

Ferubko Ekaterina Vladimirovna - Ph. D. (Med.)

Head of department of experimental pharmacology, All-Russian scientific research institute of Medicinal and

Aromatic plants, RUSSIA.

E-mail: eferubko@yandex.ru

History

- Submission Date: 14-02-2021;

- Review completed: 28-03-2021.

- Accepted Date: 02-04-2021.

DOI : 10.5530/pj.2021.13.91

Article Available online http://www.phcogj.com/v13/i3

\section{Copyright}

(C) 2021 Phcogj.Com. This is an openaccess article distributed under the terms of the Creative Commons Attribution 4.0 International license.

\section{ABSTRACT}

Background: The aim of this work is pharmacognostic study of herbal formulation consisting of elecampane rhizomes and roots (Inula helenium L.), fruits of rose (Rosa sp.) and hawthorn (Crataegus sp.), leaves of pepper mint (Mentha piperita L.) and cowberry leaves (Vaccinium vitis-idaea L.), spiny eleuterococcus rhizomes and roots (Eleutherococcus senticosus (Rupr.et Maxim.) Maxim., low cudweed herb (Gnaphalium uliginosum L.s.I.) as well as determination of its hepatoprotective activity. Materials and methods: An electron microscope, HPLC and methods of the State Pharmacopoeia of Russia were used in pharmacognostic study of herbal formulation. The hepatoprotective, antioxidant and choleretic activities of the herbal formulation were studied in vivo model of liver damage induced by tetracycline hydrochloride and $40 \%$ ethanol. Results: The content of biologically active substances (BAS) collected: essential oils - at least $0.30 \%$; flavonoids in terms of luteolin - not less than $1.0 \%$; ascorbic acid - not less than 0.5\%; tannins - not less than 3.0\%; arbutin - at least $0.4 \%$; eleutheroside $\mathrm{B}$ - not less than $0.01 \%$.It has been found that the course administration of herbal formulation to white Wistar rats with liver damage eliminates the prooxidant effect of tetracycline and ethanol, reduces the manifestation of cholestasis and increases the rate of bile secretion for 1-3 hours. Conclusion: The herbal formulation has hepatoprotective activity, antioxidant, choleretic effect and stimulates regenerative and antitoxic processes in the liver in rats with a model of combined liver damage induced tetracycline and ethanol. The obtained research results argue the possibility of using herbal formulation for prevention and complex treatment of liver diseases.

Key words: Microscopy, Phenolic compounds, Standardization, Hepatoprotective activity

\section{INTRODUCTION}

According to statistics for 2014-2018, in the Siberian Federal District the number of patients per 100 thousand people (with a diagnosis established for the first time in their lives) with liver disease is $21-36 \%$ higher and with fibrosis and cirrhosis it is higher by $33-36 \%$ than the all-Russian indicators. ${ }^{1}$

The cold climatic conditions in Siberia, the poor standard of the population living and the traditional use of fatty foods and alcohol leading to liver diseases are the reasons of this situation. In the treatment of liver diseases, herbal drugs are widely used, which are advantageously distinguished from synthetic ones by a softer, sparing effect on the patient's body., ${ }^{2,3}$

Today, the list of herbal hepatoprotectors allowed in Russia for the treatment of liver diseases is not large and includes several items (hepabene, sibektan, maksar, karsil, silymarin, etc. ${ }^{4}$ ), while the problem of effective therapy is far from being resolved. Herbal formulations are the most affordable and cheapest drug form and remain popular among the population.

Previously the anti-inflammatory activity, ${ }^{5}$ antioxidant activity (AOA) of aqueous extracts of the herbal formulation and its components in vitro. ${ }^{6}$ and the chemical composition of volatile compounds of essential oil ${ }^{7}$ were studied. Water soluble substances of cowberry leaves, pepper mint leaves, fruits of rose and low cudweed herb were found to make the most significant contribution to the AOA of the herbal formulation.

The purpose of this work was to establish parameters required for quality control of the herbal formulation based on pharmacognostic studies and to determine its hepatoprotective effect on combined liver damage induced by tetracycline and ethanol.

\section{MATERIALS AND METHODS}

The object of study was 7-component herbal formulation consisting of pharmacopoeial medicinal plants: elecampane rhizomes and roots (Inula helenium L.)- $250 \mathrm{~g}$, fruits of rose (Rosa sp.) - $200 \mathrm{~g}$, fruits of hawthorn (Crataegus sp.) - $200 \mathrm{~g}$, leaves of pepper mint (Mentha piperita L.) - $100 \mathrm{~g}$, cowberry (Vaccinium vitis-idaea L.) leaves - $100 \mathrm{~g}$, spiny eleuterococcus rhizomes and roots (Eleutherococcus senticosus (Rupr.et Maxim.) Maxim. - 100 g, low cudweed herb (Gnaphalium uliginosum L.s.l.) - $50 \mathrm{~g}$. Herbal formulation samples were prepared at MIP "Arura" (Ulan-Ude, Russia) from pharmacopoeial raw materials produced by "Travy Bashkirii" (Ufa, Russia).

The raw materials were crushed separately for the herb formulation preparation: rhizomes and roots

Cite this article: Lubsandorzhieva PB, Rendyuk TD, Dashinamzhilov ZhB, Dargaeva TD Ferubko EV. Pharmacognostic Study of Collection and Study of its Hepatoprotective Activity. Pharmacog J. 2021;13(3): 713-21. 
of elecampane and spiny eleuterococcus, cowberry leaves - up to a particle size of $3 \mathrm{~mm}$, pepper mint leaves - $5 \mathrm{~mm}$, low cudweed herb $-7 \mathrm{~mm}$, rose and hawthorn fruits $-2 \mathrm{~mm}$, as documented in the State Pharmacopoeia of the Russian Federation. ${ }^{8} 10 \mathrm{~g}$ of the herb formulation were sieved through a sieve with a diameter of $0.18 \mathrm{~mm}$ for screening vegetable dust, 25-30 fragments were collected for each component of the herbal formulation and glued to a disk with a diameter of $25 \mathrm{~mm}$ in dry form for analysis using Hitachi TM 1000 electron microscope.

The study of phenolic composition and the quantitative determination of eleutheroside $B$ in herbal formulation were carried out on a HPLC (Gilson, France) and manual injector (Rheodyne 7125, USA) with following computer processing of the results (Multichrom program for Windows). As the stationary phase there was used a metal column $(4.6 \times 250 \mathrm{~mm})$ filled with Chromasil C18; particle size - 5 microns. As a mobile phase there was used methanol-water - concentrated phosphoric acid (400: 600: 5). The analysis was carried out at room temperature. The rate of eluent was $0.8 \mathrm{~mL} / \mathrm{min}$. The duration of the analysis was $50 \mathrm{~min}$. Detection for phenolic composition determination was carried out with the use of UV detector (Gilson UV/VIS, 151) at $254 \mathrm{~nm}$ and for quantitative determination of eleutheroside $B$ at 266 nm wavelength.

The following standard samples of compounds were used for identification of substances in the herb formulation: rutin (Sigma Aldrich, USA, cat. No. R5143; $\geq 94 \%$ ), quercetin (Sigma Aldrich, USA, cat. No. Q4951; $\geq 95 \%$ ), luteolin (Sigma Aldrich, USA, Cat.No. L9283; $\geq 98 \%$ ), gallic acid (Sigma Aldrich, USA, Cat.No. G7384; $\geq 97.5 \%$ ), caffeic acid (SigmaAldrich, USA, Cat.No. C0625; $\geq 98 \%$ ), chlorogenic acid (Sigma Aldrich, USA, cat. No. C3878; $\geq 95 \%$ ), hyperoside (Sigma Aldrich, USA, cat. No. 83388; $\geq 97 \%$ ), ferulic acid (Sigma Aldrich, USA, cat. No. 128708; $\geq 99 \%$ ), neochlorogenic acid (SigmaAldrich, USA, cat No. 94419; $\geq 98 \%$ ), chicoric acid (SigmaAldrich, USA, cat. No. C7243; $\geq 95 \%$ ), epicatechin (Sigma Aldrich, USA, cat. No. E1753; $\geq 90 \%$ ) and epigallocatechin gallate (Sigma Aldrich, USA, cat. No. E4143; $\geq 95 \%$ ), eleutheroside $B$ - FC 42-89-02 (RU).

Identification of individual substances was carried out by comparing retention times of peaks in the chromatogram of the tested solution with those in the standard solution chromatogram. The quantitative ratio of identified substances in the tested samples was estimated according to peaks square with the use of the internal normalization method.

\section{Sample preparation for HPLC analysis}

Herbal formulation was crushed to particles passing through a sieve with an opening size of $1 \mathrm{~mm}$. Precisely weighed amount $(\approx 2.0 \mathrm{~g})$ of crushed herbal formulation was put into round bottomed flask (V $=100 \mathrm{mLl}$ ) and $20 \mathrm{~mL}$ of $70 \%$ ethyl alcohol was added; the flask was heated at reflux on a water bath for 1 hour after boiling of the alcohol mixture. After cooling the mixture was filtered through a paper filter into measuring flask $(\mathrm{V}=25 \mathrm{~mL})$ and then ethanol was made up the volume (solution A). At the same time the series of $0.05 \%$ solutions of standard samples of phenolic compounds, namely, the solution of rutin, quercetin, luteolin, gallic acid, caffeic acid, chlorogenic acid, hyperoside, ferulic acid, neochlorogenic acid, chicoric acid, epicatechin, epigallocatechin gallate, eleutheroside $B$ were prepared in $70 \%$ ethanol. The tested solutions and solutions of standard substances in volume of $50 \mu \mathrm{L}$ each were chromatographed according to the above method.

Quantitative determination of the content of the main groups of biologically active substances (BAS) was carried out using the methods of the State Pharmacopoeia of the Russian Federation XIV edition: eleutheroside $B$ - by HPLC; arbutin - by chromatospectrophotometric method; essential oils - by the hydrodistillation method with a Clevenger apparatus; tannins and organic acids in terms of malic acid - by titrimetric method; flavonoids, anthocyanins, ascorbic acid, carotenoids in terms of $\beta$-carotene - by spectrophotometric method. ${ }^{8}$ The modified anthron-sulfur method and coefficient of the conversion to monosaccharide (glucose - 358, galacturonic acid - 214) were used for the quantity determination of the polysaccharides group composition. ${ }^{9}$

The pharmacological studies were carried out in accordance with the Federal Law of the Russian Federation "On Circulation of Medicines", "Guidelines for Preclinical Trials of Medicinal products". The experiments were carried out on 84 non-linear rats of both sexes with an initial body weight of 180-200 g. Animals were received from the Federal State-Funded Scientific Institution "Scientific Center for Biomedical Technologies" of the Federal Medical and Biological Agency of Russia and kept in vivarium with free access to food and water. Pharmacological studies were carried out in accordance with the Order of the Ministry of Health of the Russian Federation No. 199n of April 1, 2016 "On approval of the Rules of Good Laboratory Practice" and in accordance with GLP. ${ }^{10}$ The studies were approved by the local Bioethics Committee (Protocol No. 2 of February 15, 2017).

A combined liver damage in rats was simulated by intragastric administration of tetracycline hydrochloride dissolved in Tween-80 (1:10) at a dose of $0.5 \mathrm{~g} / \mathrm{kg}$ animal weight. 3 hours after tetracycline administration the $40 \%$ water solution of ethanol was administered to rats at the dose $12,5 \mathrm{~mL} / \mathrm{kg}$ once a day for 7 days.

Herbal formulation infusion (1:10) was prepared according to the method of the State Pharmacopoeia ${ }^{8}$ for oral administration (infusion dry residue $-31.2 \pm 1.2 \mathrm{mg} / \mathrm{mL}$ ) and was administered to white rats once a day for 7 days at the dose $0.1 \mathrm{~mL} / \mathrm{kg}$, that corresponds to $312 \pm$ $12 \mathrm{mg} / \mathrm{kg}$ of extractive substances. The interval between administration of the herbal formulation infusion, tetracycline and ethanol was 3-5 hours. Cholosas (herbal hepatoprotective and choleretic drug) in the form of syrup registered in the Russian State Register of Medicines ${ }^{4}$ was chosen as a standard drug at the dose of $0.1 \mathrm{~mL} / \mathrm{kg}$. Animals of the control group received the same amount of purified water according to a similar scheme.

The functional state of the liver of animals was evaluated in the dynamics of the development of damage on the 7 th day from the beginning of the experiments. The hepatoprotective effect of herbal formulation and the reference drug was estimated by the activity of enzymes in serum - alanine aminotransferase (ALT) and aspartate aminotransferase (AcT) and by the content of total bilirubin, cholesterol and alkaline phosphatase activity in blood serum. The intensity of lipid peroxidation (LPO) was evaluated by the content of malonic dialdehyde (MDA) in the liver tissue homogenate. The state of the antioxidant defense of the body was evaluated by the level of catalase activity in blood serum.

In order to study the choleretic effect of herbal formulation, white rats received the single dose of $0.1 \mathrm{~mL} / \mathrm{kg}$ infusion. Bile samples were taken from an anesthetized animal (sodium thiopental, $45 \mathrm{mg} / \mathrm{kg}$ ) through a polyethylene cannula inserted into the common bile duct. The samples were collected every hour during 4 hours. The choleretic activity of this herbal formulation was estimated by the rate of secretion and the amount of total excreted bile, by the level of bilirubin, bile acids and cholesterol.

Antitoxic liver function was evaluated by the duration of hexenal sleep in white rats. Hexenal was administered to animals intraperitoneally once a day at a dose of $70 \mathrm{mg} / \mathrm{kg}$ of rat weight.

Analytical chemical data were statistically processed using Microsoft Excel 2010 application programs in accordance with the State Pharmacopoeia of the Russian Federation XIV edition (OFS 1.1.0013.15) ${ }^{8}$, and pharmacological experiments were performed using Statistica Software program version 6.0 (USA). Data were expressed as an average value $(\mathrm{M} \pm \mathrm{m})$, the significance of differences in average values between groups was evaluated using Student's t-test (for independent groups, differences were considered significant at $\mathrm{P}$ $\leq 0.05)$. 


\section{RESULTS}

The most significant anatomical features for each component of herbal formulation were revealed as a result of a microscopic study of large particles of the herbal formulation (particle size 2-7 mm), (Figure 1).

Fragments of essential oil cavity (Figure 1, A) and rounded parenchymal cells (Figure 1, B) on fragments of elecampane rhizomes and roots; prismatic crystals of calcium oxalate (Figure 1, C, 1), pigment cells with mucous epidermis (Figure 1, C, 2) and stony cells of endocarp (Figure $1, \mathrm{D})$ on fragments of the seed coat of hawthorn fruits; fragments of unicellular trichomes of the internal epidermis of the fruit (Figure 1, E, 3) and of the nut-shaped fruit (Figure 1, E, 4), elongated stony cells (Figure 1, F, 5) and large prismatic crystalls of calcium oxalate (Figure $1, \mathrm{~F}, 1)$ on fragments of rose fruits; unicellular conical trichomes on

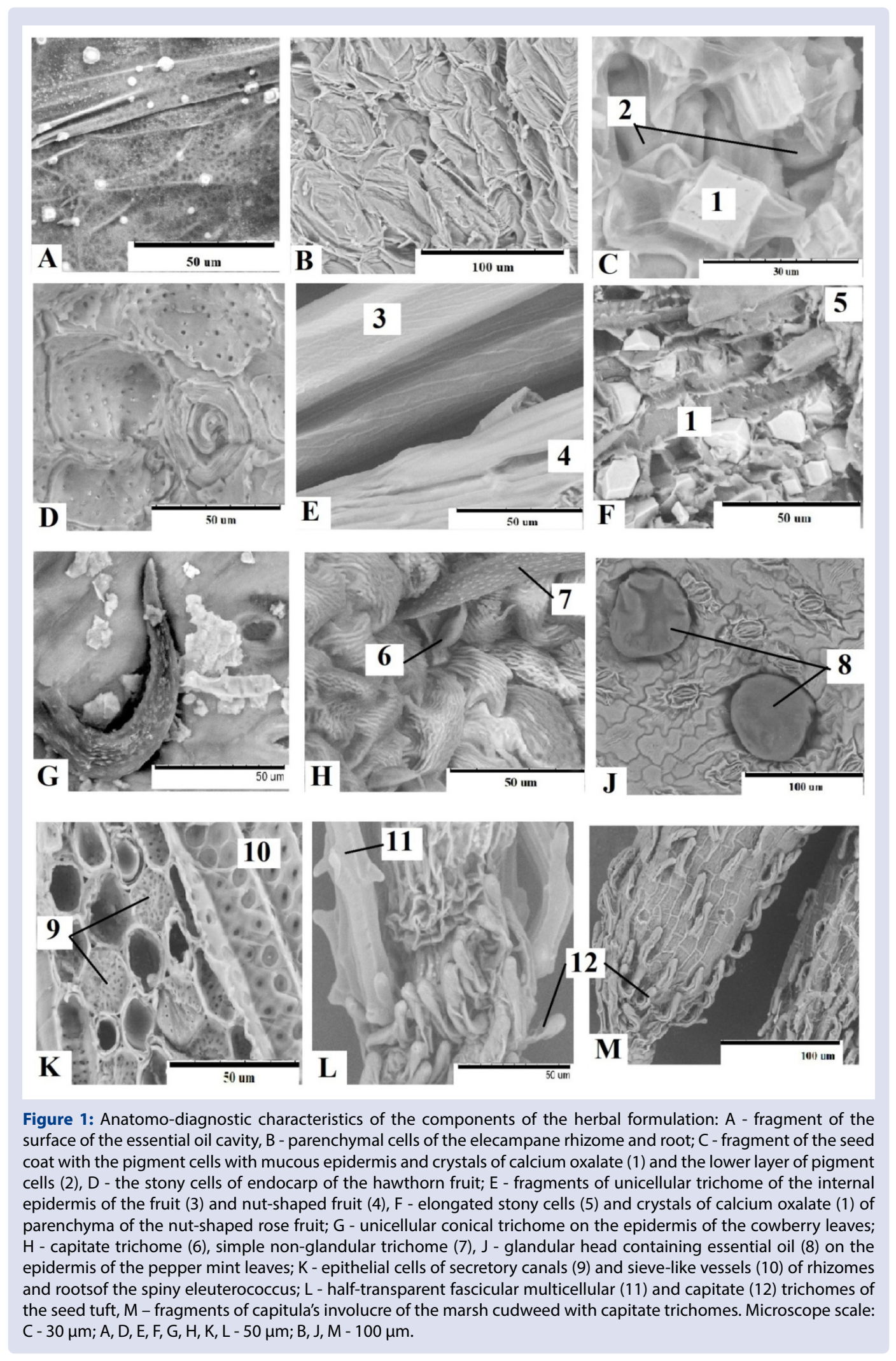


fragments of the epidermis of cowberry leaf densely covered with wax particles (Figure 1, G); capitate glandular (Figure 1, H, 6) and nonglandular trichomes with warty cuticular thickenings (Figure $1, \mathrm{H}$, 7), glandular head containing essential oil (Figure 1, J, 8), epidermal cells with sinuous walla and diacetic stomata (Figure 1. J) on the epidermis of fragments of the pepper mint leaves; epithelial cells of secretory canals (Figure 1, K, 9) and sieve-like vessels on fragments of rhizomes and roots of the spiny eleuterococcus (Figure 1, K, 10); half-transparent fascicular multicellular trichomes (Figure 1, L, 11) and capitate trichomes on fragments of the seed tuft (Figure $1 \mathrm{~L}, 12$ ); capitate trichomes on epidermis of the capitula's involucre (Figure 1, M) of the marsh cudweed herb were determined microscopically.

Thus, the detection of 1-2 anatomical specific features for each component of the herbal formulation in micropreparations is sufficient to identify the components of the herbal formulation and determine its authenticity.

Ten compounds were identified in $70 \%$ ethanol extract of herbal formulation using the HPLC method (Table 1 and Figure 2).

Gallic, isoferulic and chicoric acids, catechin, eleutheroside $B$, luteolin are dominated in $70 \%$ ethanol extract of the herbal formulation. The data on the quantitative content of biologically active substances (BAS) are given in Table 2. The total flavonoid content is estimated based on the spectrophotometric method using aluminum chloride, that forms stable complexes with flavonoids in acidic solution ${ }^{8}$. The UV spectrum of the $70 \%$ ethanol extract of the herbal formulation has maximum absorption at 330 sh., $280 \pm 2$ and $218 \mathrm{~nm}$ and minimum absorption at 262 and $308 \mathrm{~nm}$, maximum absorption of complexes of flavonoids with aluminum chloride in the UV spectrum of the herbal formulation $\left(\lambda_{\text {max }}\right.$ $399 \pm 2 \mathrm{~nm})$ coincides with that of standard sample of luteolin $\left(\lambda_{\max }-\right.$ $400 \mathrm{~nm}$ ) (Figure 3).

The relative error of the average and individual results of the quantitative determination of flavonoids, arbutin, ascorbic acid, eleutheroside B, tannins does not exceed 5\% (Table 3), that is consistent with the requirements of the State Pharmacopoeia of the Russian Federation XIV edition ${ }^{8}$.

For standardization of the herbal formulation, taking into account the obtained experimental data, the content of the following active substances is regulated, namely, essential oils - at least $0.30 \%$; flavonoids in terms of luteolin - not less than $1.0 \%$; ascorbic acid - not less than $0.5 \%$; tannins - not less than $3.0 \%$; arbutin - not less than $0.4 \%$; eleutheroside $B$ - not less than $0.01 \%$.

The results of pharmacological studies of the herbal formulation are presented in tables $4-7$. It has been found that tetracycline and ethanol initiate LPO processes in the liver, as evidenced by an increase in the formation of MDA by $48 \%$.

The intensification of LPO processes causes a decrease in catalase activity by $31.2 \%$ compared with indicators of intact animals (Table 4 ). Lipoperoxidation products released under the influence of tetracycline and ethanol and proinflammatory cytokines disrupt the barrier and matrix functions of hepatocyte membranes. Their cytolytic effect is

Table 1: Phenolic compounds in $\mathbf{7 0} \%$ ethanol extract of the herbal formulation.

\begin{tabular}{cccc|}
\hline No & Compounds & Retention time, min & The content, \%, Method Internal normalization \\
\hline 1 & Gallic acid & 2,97 & 25,70 \\
2 & Catechin & 3,21 & 12,71 \\
3 & Eleutheroside $B$ & 3,58 & 10,99 \\
4 & Isoferulic acid & 3,86 & 12,00 \\
5 & Epigalljcatechin gallate & 4,62 & 4,53 \\
6 & Chlorogenic acid & 5,08 & 3,87 \\
7 & Chicoric acid & 6,03 & 5,19 \\
8 & Caffeic acid & 6,80 & 2,20 \\
9 & Ferulic acid & 13,4 & 2,44 \\
10 & Luteolin & 15,84 & 3,20 \\
\hline
\end{tabular}

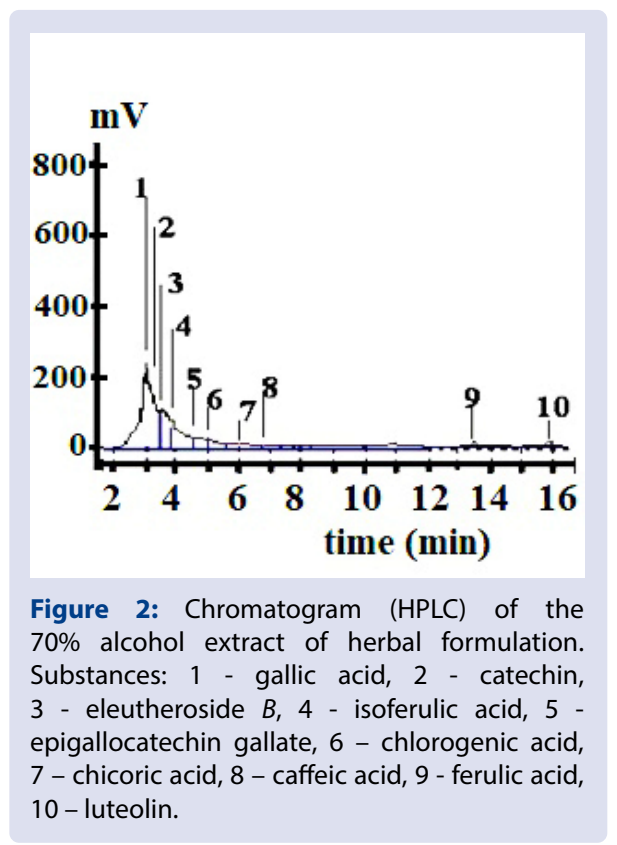




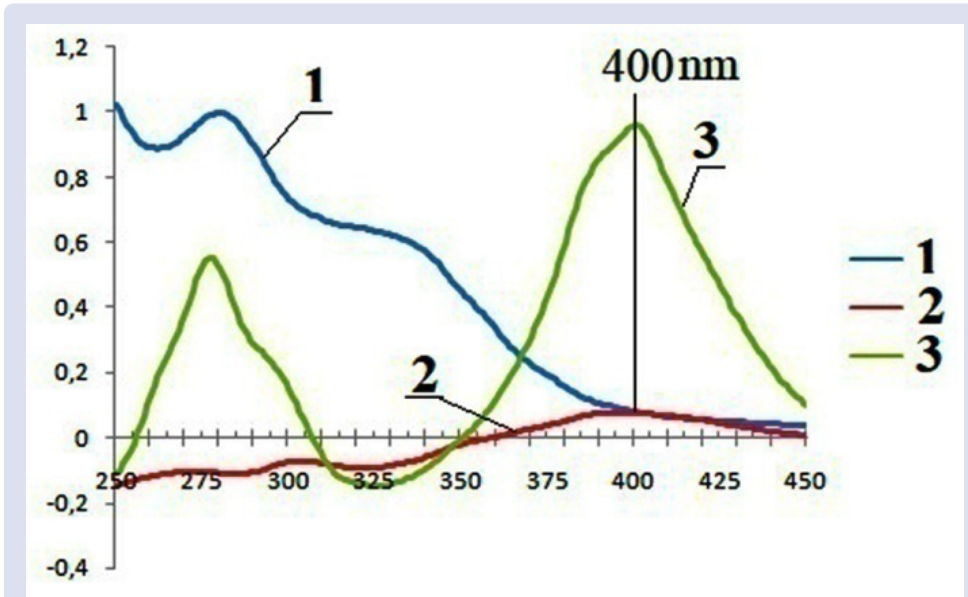

Figure 3: UV - spectrum of $70 \%$ ethanol extract (1) and differential spectra of herbal formulation (2) and luteolin (3) with the addition of a $3 \%$ solution of aluminum chloride in ethanol.

Table 2: Quantitative content of biologically active substances in the herbal formulation.

\begin{tabular}{ll} 
Name & Total content, $\%$ \\
\hline Essential oil & $0,54 \pm 0,20$ \\
Total flavonoids in term of luteolin & $1,08 \pm 0,02$ \\
Total polyphenolic substances in term of tannin & $3,52 \pm 0,02$ \\
Arbutin & $0,61 \pm 0,01$ \\
Eleutheroside $B$ & $0,0112 \pm 0,148 \times 10^{-3}$ \\
Ascorbic acid & $0,90 \pm 0,008$ \\
Total anthocyanins in term of anthocyanin-3,5-diglucoside & $0,28 \pm 0,01$ \\
Total carotenoids in term of B-carotene, $\mathrm{M \Gamma} \%$ & $4,60 \pm 0,10$ \\
Total organic acids in term malic acid & $3,75 \pm 0,01$ \\
Polysacharides composition: & \\
Monosaccharides in term of glucose & $0,83 \pm 0,01$ \\
Water soluble polysaccharides in term of glucose & $1,67 \pm 0,01$ \\
Pectins in term of galacturonic acid & $1,77 \pm 0,02$
\end{tabular}

Table 3: Metrological characteristics of methods for the quantitative determination of substances in the herbal formulation, $(P=$ 95\%).

\begin{tabular}{|c|c|c|c|c|c|c|c|}
\hline f & $x \%$ & S & $\mathrm{S}_{\mathrm{o}}$ & $t(P, f)$ & $\Delta \bar{O}$ & $\varepsilon, \%$ & $\overline{\boldsymbol{\varepsilon}}, \%$ \\
\hline \multicolumn{8}{|c|}{ Total flavonoids in term of luteolin, \% } \\
\hline 10 & 1,08 & 0,0218 & 0,0069 & 2,23 & 0,0156 & 4,50 & 1,44 \\
\hline \multicolumn{8}{|c|}{ Arbutin, \% } \\
\hline 5 & 0,49 & 0,0008 & 0,0035 & 2,57 & 0,0091 & 4,55 & 1,86 \\
\hline \multicolumn{8}{|c|}{ Ascorbic acid, \% } \\
\hline 5 & 0,90 & 0,0120 & 0,0045 & 2,57 & 0,0111 & 3,42 & 1,27 \\
\hline \multicolumn{8}{|c|}{ Eleutheroside $B, \%$} \\
\hline 5 & 0,01 & $0,141 \times 10^{-3}$ & $0,057 \times 10^{-3}$ & 2,57 & $0,148 \times 10^{-3}$ & 3,01 & 1,23 \\
\hline \multicolumn{8}{|c|}{ Total polyphenolic substances in term of tannin, $\%$} \\
\hline 6 & 3,54 & 0,0709 & 0,0268 & 2,45 & 0,0656 & 4,90 & 1,85 \\
\hline
\end{tabular}

Note: $\mathrm{f}$ - variability, $\bar{O}$ - mean, $\mathrm{S}$ - standart deviation, $\mathrm{S}_{\bar{o}}$ - standart deviation of estimate of mean, $\overline{\bar{\varepsilon}}-$ confidence figure, $\Delta \overline{\tilde{O}}$ - half-width of the confidence interval of the average result; $\varepsilon$-relative error of the result of separate definition, ${ }^{\varepsilon}$ - relative error of the result of average definition \%.

accompanied by the release of ALT, AST into the blood of the liver parenchyma, their activity increases by 41 and 35\%, respectively, as compared to the intact group, that indicates the onset of the inflammatory process. Cholestasis syndrome also develops along with the increase of concentration of total bilirubin by 3.0 times, cholesterol by $33.8 \%$, $ß$-lipoproteins by 2.5 times and alkaline phosphatase activity by $35 \%$ in blood (Table 4 ).
The herbal formulation eliminates the prooxidant effect of tetracycline and ethanol: the MDA content in the liver tissue decreased by $56.4 \%$ in the experimental group on the 7 th day of the experiment. The activity of serum catalase is increased by $32 \%$, that contributes to the increase in the activity of the endogenous antioxidant system of the body (Table 4).

The activity of enzymes of hepatic origin in the blood under the influence of BAS of herbal formulation is reduced by 23 and $14 \%$. 
Table 4: Effect of herbal formulation infusion on biochemical indicators in white rats with combined liver damage induced with tetracycline and ethanol.

\begin{tabular}{|c|c|c|c|c|}
\hline Biochemical indicators & Intact rats & $\begin{array}{l}\text { Control rats (tetracycline + } \\
\text { ethanol + distilled water) }\end{array}$ & $\begin{array}{c}\text { Experimental rats } \\
\text { (tetracycline }+ \text { ethanol }+ \\
\text { herbal formation) }\end{array}$ & $\begin{array}{c}\text { Experimental rats } \\
\text { (tetracycline + ethanol } \\
+ \text { Cholosas) }\end{array}$ \\
\hline МДА, nmol /g tissue & $2,10 \pm 0,01$ & $3,12 \pm 0,04$ & $1,76 \pm 0,02^{*}$ & $1,75 \pm 0,01^{*}$ \\
\hline $\mathrm{ALT}, \mu \mathrm{M} / \mathrm{mL} \cdot \mathrm{h}$ & $3,08 \pm 0,10$ & $4,36 \pm 0,11$ & $3,36 \pm 0,12$ & $4,81 \pm 0,10^{*}$ \\
\hline AST, $\mu \mathrm{M} / \mathrm{mL} \cdot \mathrm{h}$ & $1,87 \pm 0,12$ & $2,53 \pm 0,10$ & $2,45 \pm 0,09^{*}$ & $2,43 \pm 0,2^{*}$ \\
\hline Total cholesterol, mM/L & $1,39 \pm 0,02$ & $1,86 \pm 0,12$ & $1,22 \pm 0,01^{*}$ & $1,27 \pm 0,01^{*}$ \\
\hline Alkaline phosphatase, units & $7,85 \pm 0,90$ & $10,65 \pm 0,90$ & $7,00 \pm 0,90^{*}$ & $9,15 \pm 0,90$ \\
\hline Total bilirubin, $\mu \mathrm{M} / \mathrm{L}$ & $6,26 \pm 0,90$ & $18,97 \pm 1,10$ & $12,35 \pm 1,20^{*}$ & $16,83 \pm 1,30$ \\
\hline$\beta$-lipoproteids, relative units & $2,05 \pm 0,15$ & $5,45 \pm 0,11^{*}$ & $4,46 \pm 0,10^{*}$ & $4,76 \pm 0,20^{*}$ \\
\hline $\begin{array}{l}\text { Catalase activity of blood } \\
\text { serum, } \mathrm{mg} / \mathrm{H}_{2} \mathrm{O}_{2}\end{array}$ & $3,81 \pm 0,50$ & $2,62 \pm 0,20$ & $3,47 \pm 0,10^{*}$ & $3,00 \pm 0,10^{*}$ \\
\hline
\end{tabular}

Note: Here and elsewhere below asterisk * denote that the differences between control and experimental groups are significant at $\mathrm{P}<0,05$.

Table 5: The effect of the herbal formulation infusion on the rate of bile secretion in white rats with combined liver damage induced ethanol and tetracycline $(M \pm m)$.

\begin{tabular}{|c|c|c|c|c|c|}
\hline \multirow{2}{*}{$\begin{array}{l}\text { Experimental } \\
\text { conditions }\end{array}$} & \multicolumn{4}{|c|}{ Bile excretion rate during 4 hours, $\mathrm{mg} / \mathrm{min}$ per $100 \mathrm{~g}$ of body weight } & \multirow{2}{*}{$\begin{array}{c}\text { Total amount of bile } \\
\text { excreted during } 4 \\
\text { hours, } \mathrm{mg} / 100 \mathrm{~g}\end{array}$} \\
\hline & 14 & 24 & 34 & 44 & \\
\hline & \multicolumn{5}{|c|}{7 days } \\
\hline Intact rats & $5,0 \pm 0,1$ & $5,7 \pm 0,3$ & $6,8 \pm 0,3$ & $6,7 \pm 0,2$ & $1410 \pm 50$ \\
\hline $\begin{array}{c}\text { Control rats } \\
\text { (tetracycline }+ \text { ethanol } \\
+ \text { distilled water })\end{array}$ & $4,6 \pm 0,1^{*}$ & $4,0 \pm 0,3^{*}$ & $5,5 \pm 0,2^{*}$ & $6,5 \pm 0,2^{*}$ & $1190 \pm 11,0^{*}$ \\
\hline $\begin{array}{c}\text { Experimental rats } \\
\text { (tetracycline + ethanol } \\
+ \text { herbal formation) }\end{array}$ & $5,7 \pm 0,3^{*}$ & $5,0 \pm 0,2^{*}$ & $6,0 \pm 0,2$ & $5,5 \pm 0,2^{*}$ & $1320 \pm 17^{*}$ \\
\hline $\begin{array}{c}\text { Experimental rats } \\
\text { (tetracycline + ethanol } \\
\text { +Cholosas) }\end{array}$ & $4,7 \pm 0,4$ & $5,0 \pm 0,2^{*}$ & $5,2 \pm 0,3$ & $5,0 \pm 0,3^{*}$ & $1250 \pm 18^{*}$ \\
\hline
\end{tabular}

Table 6: Effect of the herbal formulation infusion on the level of bile acids, bilirubin and cholesterol in white rats with combined liver damage induced ethanol and tetracycline.

\begin{tabular}{|c|c|c|c|}
\hline \multirow{3}{*}{ Experimental conditions } & \multicolumn{3}{|c|}{ Amounts in bile, $\mathrm{mg} / 100 \mathrm{~g}$ weight } \\
\hline & Bile acids & bilirubin & cholesterin \\
\hline & \multicolumn{3}{|c|}{7 сутки } \\
\hline Intact rats & 0,106 & 0,092 & 1,80 \\
\hline $\begin{array}{l}\text { Control rats (tetracycline }+ \text { ethanol } \\
+ \text { distilled water) }\end{array}$ & 0,044 & 0,085 & 1,54 \\
\hline $\begin{array}{l}\text { Experimental rats (tetracycline }+ \\
\text { ethanol }+ \text { herbal formation) }\end{array}$ & 0,076 & 0,095 & 1,87 \\
\hline $\begin{array}{c}\text { Experimental rats (tetracycline }+ \\
\text { ethanol }+ \text { Cholosas) }\end{array}$ & 0,042 & 0,085 & 1,55 \\
\hline
\end{tabular}

Table 7: Effect of the herbal formulation infusion on the duration of hexenal sleep in white rats with combined liver damage (tetracycline + ethanol) (7 days).

\begin{tabular}{llll} 
Intact rats & $\begin{array}{l}\text { Control rats (tetracycline } \\
\text { ethanol + distilled water) }\end{array}$ & $\begin{array}{c}\text { + Experimental rats } \\
\text { ethanol + herbal formation) }\end{array}$ & $\begin{array}{c}\text { (tetracycline } \\
+ \text { Experimental rats (tetracycline } \\
+ \text { ethanol +Cholosas) }\end{array}$ \\
\hline $14,20 \pm 1,0$ & $17,90 \pm 1,40$ & $13,50 \pm 1,20^{*}$ & $14,00 \pm 1,40$
\end{tabular}

The herbal formulation reduces the manifestation of cholestasis, as evidenced by the decrease of cholestasis markers in blood - alkaline phosphatase by $34.3 \%$, cholesterol by $35,0 \%$, B-lipoproteins $-19,0 \%$ and bilirubin by $34,9 \%$ (Table 4 ).

The administration of tetracycline in combination with ethanol inhibits the bile formation function of the liver, the content of cholates in the bile decreases by $58,5 \%$, bilirubin - by $8 \%$, cholesterol - by $15 \%$, while the total amount of bile decreases by $16 \%$ on the 7 th day of observation (Table 5, 6).
The herbal formulation has more pronounced choleretic effect compared to Cholosas: when using this herbal formulation infusion, the rate of bile secretion increases within 1-3 hours, and Cholosas within 1-2 hours. The concentration of the main bile ingredients increases against this background: bile acids by $-72,7 \%$, bilirubin - by $11,7 \%$, cholesterol - by $21,1 \%$ (Table 6 ). Thus, the infusion of the herbal formulation has pronounced hepatoprotective and choleretic activity in the experiment on rats.

The improvement in the antitoxic function of the liver in white rats is noticed against the background of the administration herbal 
formulation infusion, as evidenced by a reduction in the duration of hexenal sleep in white rats by $25 \%$ as compared to the control on day 7 (Table 7).

\section{DISCUSSION}

Based on the studies carried out, the presence and content of the main BAS in the collection and its hepatoprotective activity were established.

HPLC evaluated the content of BAB: gallic acid, catechin, eleutheroside $\mathrm{B}$, isoferulic acid, epigallocatechingallate, chlorogenic, cyclic, coffee, ferulic acid, luteolin.

Essential oil (pepper mint, elecampane), flavonoids (low cudweed, rose, hawthorn, pepper mint), tannins (cowberry and other components of herbal formulation), polysaccharides (elecampane, rose and hawthorn fruits, spiny eleuterococcus), arbutin (cowberry), eleutherosides (spiny eleuterococcus), ascorbic acid (rose fruit) are the main active ingredients of herbal formulation (Table 2).

Synergistic or antagonistic reactions of BAS to cell signal systems during inflammatory reactions and oxidative stress are usually present in the mechanism of action of herbal remedies. The protective effect of the herbal formulation in combined liver damage can be achieved due to the hepatoprotective and choleretic activity of eleutherosides, sesamine, isofraxidin of the spiny eleuterococcus ${ }^{11}$ and BAS of the low cudweed ${ }^{12}$. Flavonoids, tannins have hepatoprotective activity ${ }^{13}$, phenylpropanoids of the hawthorn fruits exhibit cytotoxic activity against liver carcinoma cells inducing apoptosis ${ }^{14}$.

Also, sesquiterpenoids, alantolactone of the elecampane ${ }^{15-16}$ having anti-inflammatory effects; BAS of spiny eleuterococcus ${ }^{11,17}$ modulating the immune response in inflammation ${ }^{11}$ and BAS of cowberry leaves possessing antitoxic activity ${ }^{18}$ play an important role in achieving the pharmacological effect of the herbal formulation.

Oxidative stress plays a key role in the pathogenesis of alcoholic and toxic liver damage ${ }^{19}$, natural antioxidants are important in its therapy. The antioxidant activity of herbal formulation established previously in $v i t r o^{6}$ was confirmed in animal experiment in this work: herbal formulation infusion reduced the intensity of the LPO process, that significantly contributed to an increase in the activity of the endogenous antioxidant defense of the body, the catalase activity in the experimental group increased and exceeded that of the control group (Table 4). AOA of herbal formulation is realized through the AOA of phenolic compounds of the low cudweed herb ${ }^{20}$, hawthorn ${ }^{21}$ and rose fruits $^{22-23}$, elecampane ${ }^{24}$ and spiny eleuterococcus rhizomes and roots ${ }^{25}$, proanthocyanidins and flavonoids of cowberry leaves ${ }^{26,27}$, flavones, flavanones, phenolic acids ${ }^{28}$ and essential oil of pepper mint leaves ${ }^{29}$.

Thus, the studied herbal formulation in the experiment on animals with liver damage induced tetracycline and ethanol has the pronounced hepatoprotective and choleretic effect due to the presence of phenolic antioxidants that have proven antioxidant, hepatoprotective, antiinflammatory and choleretic properties.

\section{CONCLUSION}

Eleutheroside $B$, catechin, epigallocatechin gallate, luteolin, chlorogenic, chicoric, caffeic, ferulic, gallic and isoferulic acids were identified in the 7-component herbal formulation using the HPLC method. The herbal formulation was standardized for the content of active substances: essential oils - not less than $0.30 \%$; flavonoids in terms of luteolin - not less than $1.0 \%$; ascorbic acid - not less than $0.5 \%$; tannins - not less than $3.0 \%$; arbutin - not less than $0.4 \%$; eleutheroside $B$ - not less than $0.01 \%$.

The multicomponent herbal formulation has the antioxidant and choleretic effect, stimulates regenerative processes in the liver and is not inferior in terms of hepatoprotective activity to the reference drug
- Cholosas in the model of combined liver damage induced tetracycline and ethanol in rats. The obtained results argue the possibility of using the 7-component collection in prevention and complex treatment of liver diseases.

\section{CONFLICTS OF INTERESTS}

Authors declare no conflicts of interest.

\section{REFERENCES}

1. The incidence of the population of the Russian Federation. URL: URL: www.mednet.ru/statistica/zabolevaemost-naseleniya.html / [Cited 2020 March 2].

2. Prete AD, Scalera A, ladevaia MD, Miranda A, Zulli C, Gaeta L, et al. Herbal products: benefits, limits and applications in chronic liver disease. Evidence-Based Complementary and Alternative Medicine. 2012:Article ID 837939. 19 pp.

3. Ghosh N, Ghosh R, Mandal V, Mandal S. Recent advances in herbal medicine for treatment of liver diseases. Pharmaceutical Biology 2011;49:970-88.

4. State Register of medicines of the Russian Federation. URL: https:// grls.rosminzdrav.ru/ [cited 2020 March 2].

5. Dashinamzhilov ZB, Ludsandorzhieva PB, Nikolaev SM. Antiinflammatory effect of seven-component herbal tea "Narkophyt". Experimental and clinical pharmacology. 2010;73(5):33-5.

6. Lubsandorzhieva PB, Dazhinamzhilov ZB. A Quantity of water soluble antioxidants in 7-component herb tea "Narkophyte". Bulletin of the VSSC SB RAMS (Acta Biomedica Scientifica). 2011;1:152-4.

7. Lubsandorzhieva PB, Boldanova NB, Soktoeva TE. Chemica composition of essential oil of hepatoprotective herb tea. Siberian medicinal journal. 2013;2:99-101.

8. State Pharmacopoeia of the Russian Federation XIV ed. URL: http:// femb.ru/feml.

9. Olennikov DN. Structural and functional study of biopolymers of plant and basidiological origin and improvement of methods for their analysis [dissertation]. Dr. Farm. Sciences; Institute of General and Experimental Biology SB RAS, Ulan-Ude, Russia, 2012.

10. Image reproduced from ICH. M4: The Common Technical Document. Retrieved 25 June, 2015, URL: http:///www.ich.org/products/ctd.htm [cited 2018 Febrary 15].

11. Davydov M, Krikorian AD. Eleuterococcus senticosus (Rupr.\& Maxim.) Maxim. (Araliaceae) as an adaptogen: a closer look. Journal of Ethnopharmacology. 2000;72:345-93.

12. Shikov AN, Kundracikova M, Palama TL, Pozharitskaya ON, Kosman VM, Makarov VG, et al. Phenolic constituents of Gnaphalium uliginosum L. Phytochemistry Letters. 2010;3:45-7.

13. Jadeja RN, Devkar PV. Polyphenols and flavonoids in controlling nonalcoholic steatohepatitis. Polyphenols in human health and disease. 2014;1:615-23.

14. Guo $R$, Lin Bin, Shang $X Y$, Zhou L, Yao GD, Huang $X X$, Soug SY. Phenylpropanoids from the fruit of Crataegus pinnatifida exhibit cytotoxicity on hepatic carcinoma cells through apoptosis induction. Fitoterapia. 2018;127:301-7.

15. KonishiT, Shimada Y, Nagao T, Okabe N, Konoshima T. Antiproliferative sesquiterpene lactones from the roots of Inula helenium. Biol. Pharm. Bull. 2002;25(10):1370-2.

16. Gierlikowska B, Gierlikowska WM, Bekier K, Skaliska-Woźniak K Czerwińska ME, Kiss AK. Inula helenium and Grindelia squarrosa as a source of compounds with anti-inflammatory activity in human neutrophils and cultured human respiratory epithelium. Journal of Ethnopharmacology. 2020;249:112311.

17. Jin L, Schmiech M, Gaafary ME, Zhang X, Syrovets T, Simmer T. A comparative study on root and bark extracts of Eleutherococcus senticosus and their effects on human macrophages. Phytomedicine. 2020;68:153181. 
18. Roman I, Puică C, Toma VA. The effect of Vaccinium vitis-idaea L. extract administration on kidney structure and function in alcohol intoxicated rats. Studia Universitatis "Vasile Goldiș." Seria Ștințele Vietii. 2014;4:363-7.

19. Galicia-Moreno M, Gutiérrez-Reyes G. The role of oxidative stress in the development of alcoholic liver disease. Revista de Gastroenterología de México. 2014;72(2):135-44.

20. Sharonova NL, Bushmeleva K. Phytochemical contents, antimicrobial and antioxidant properties of Gnaphalium uliginosum L. ethanolic extract and essential oil for agricultural uses. Asian Journal of Chemistry. 2019;31(11):2672-8.

21. Sokol-Letowska A, Oszmianski J, Wojdylo A. Antioxidant activity of the phenolic compounds of hawthorn, pine and skullcap. Food Chemistry. 2007;103:853-9.

22. Petrova SN, Ivkova AV. Chemical composition and antioxidant properties of species of the genus Rosa L. (review). Khimija Rastitel'nogo Syr'ja. 2014;2:13-9.

23. Koszka N, Stefanovits-Bányai E, Ombodi A. Total polyphenol content and antioxidant capacity of rosehips of some Rosa species. Medicines. 2018;5:84.
24. Spiridon J, Nechita CB, Marius N, Silion M. Antioxidant and chemical properties of Inula helenium root extracts. Central European Journal of Chemistry. 2013;11(10):1699-709.

25. Shetty N, Narika V, Lokras S. Antioxidant activity and total phenol and flavonoids analysis of Siberian gingeng root. International Journal of Current Pharmaceutical Research. 2020;12 (1):38-40.

26. Ho KY, Huang JS, Tsai CC, Lin TS, Hsu YF, Lin CC. Antioxidant activity of tannin components from Vaccinium vitis-idaea L. J. Pharm. and Pharmacol. 1999;51(9):1075-8.

27. Raudone L, Vilkickyte G, Pitkauskaite L, Raudonis R. Antioxidant activities of Vaccinium vitis-idaea $L$. leaves within cultivars and their phenolic compounds. Molecules. 2019;24:844.

28. Dorman HJD, Kosar M, Baser KH, Hiltunen R. Phenolic profile and antioxidant evaluation of Mentha x piperita L. (peppermint) extracts. Nat. Prod. Com. 2009;4(4):535-42.

29. Sun Z, Wang H, Wang J, Zhou L, Yang P. Chemical composition and anti-inflammatory, cytotoxic and antioxidant activities of essential oil from leaves of Mentha piperita grown in China. PLoS ONE. 2014;9(12):e114767. 


\section{GRAPHICAL ABSTRACT}

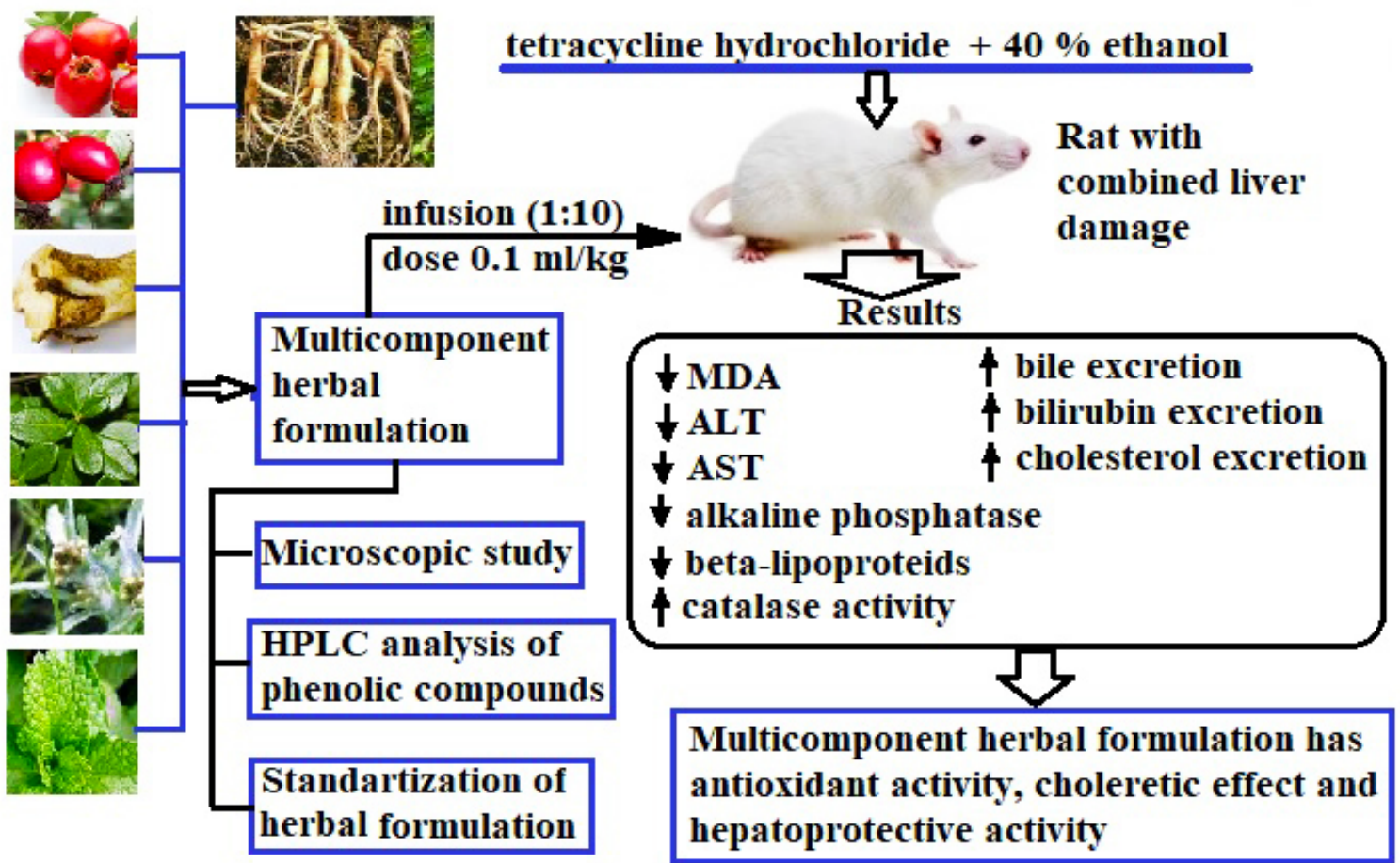

\section{ABOUT AUTHORS}

- Lubsandorzhieva Puntsyk-Nima Bazyrovna: Doctor of Pharmaceutical Sciences, Senior Researcher, Laboratory of Biomedical Research, Institute of General and Experimental Biology OF THE Siberian Branch of the RAS (Russia, UlanUde). Research interests: search for promising sources of biologically active substances and the creation on their basis of highly effective herbal medicines

- Randyuk Tamara Danilovna: Candidate of Pharmaceutical Sciences, Associate Professor, Department of Pharmaceutical natural Sciences, Institute of Pharmacy, Sechenov University (Russia, Moscow). Research interests: search for promising sources of biologically active substances and the creation on their basis of highly effective herbal medicines

- Dashinamzhilov Zhargal Balduevich: Doctor of Medical Sciences, Senior Researcher at the Laboratory for the Safety of Biologically Active Substances of the Institute of General and Experimental Biology of the Siberian Branch of the RAS (Russia, Ulan-Ude). Research interests: the study of targeted pharmacological activity and toxicology of promising herbal medicines.

- Dargaeva Tamara Darizhapovna: Doctor of Pharmaceutical Sciences, Professor, Chief Researcher at the Department of Chemistry of Natural Compounds, All-Russian Research Institute of Medicinal and Aromatic Plants (Moscow, Russia). Research interests: search for promising sources of biologically active substances and the creation on their basis of highly effective herbal medicines.

- Ferubko Ekaterina Vladimirovna:-Candidate of Medical Sciences, Head of Department of Experimental Pharmacology, All-Russian Research Institute of Medicinal and Aromatic Plants, (Moscow, Russia). Research interests: the study of targeted pharmacological activity and toxicology of promising herbal medicines.

Cite this article: Lubsandorzhieva PB, Rendyuk TD, Dashinamzhilov ZhB, Dargaeva TD, Ferubko EV. Pharmacognostic Study of Collection and Study of its Hepatoprotective Activity. Pharmacog J. 2021;13(3): 713-21. 